\title{
Effect of Independence, Work Experience and Competence on Audit Quality with Professional Ethics as Moderating Variable
}

\author{
Diyan Hera Prasanti \\ Wita Ramadhanti \\ Novita Puspasari \\ Universitas Jenderal Soedirman \\ Jl. Profesor DR. HR Boenyamin No.708, Purwokerto, Indonesia 53122 \\ diyanheraprasanti@gmail.com
}

\begin{abstract}
This study aims to examine the effect of independence, work experience and competence on audit quality with professional ethics as a moderating variable in public accounting firms in DKI Jakarta. The population in this study were all auditors at the Public Accounting Office in DKI Jakarta. The sample of this study amounted to 80 obtained from the determination of the sample using the purposive sampling method. This is a survey research with primary data derived from questionnaires distributed to the Public Accounting Firm in DKI Jakarta. Data analysis for hypothesis testing was performed using SPSS 16 with multiple linear regression and Moderated Regression Analysis. The results of this study indicate that: Work experience has a positive effect on audit quality, competence has a positive effect on audit quality, professional ethics strengthens the influence of work experience on audit quality, and professional ethics strengthens the influence of competence on audit quality.
\end{abstract}

Keywords: Independence, Work Experience, Competence, Professional Ethics, Audit Quality

\begin{abstract}
Abstrak
Penelitian ini bertujuan untuk menguji pengaruh independensi, pengalaman kerja dan kompetensi pada kualitas audit dengan etika profesional sebagai variabel moderasi di kantor akuntan publik di DKI Jakarta. Populasi dalam penelitian ini adalah semua auditor di Kantor Akuntan Publik di DKI Jakarta. Sampel penelitian ini berjumlah 80 yang diperoleh dari penentuan sampel menggunakan metode purposive sampling. Ini adalah penelitian survei dengan data primer yang berasal dari kuesioner yang didistribusikan ke Kantor Akuntan Publik di DKI Jakarta. Analisis data untuk pengujian hipotesis dilakukan menggunakan SPSS 16 dengan regresi linier berganda dan Analisis Regresi Moderated. Hasil penelitian ini menunjukkan bahwa: Pengalaman kerja memiliki efek positif pada kualitas audit, Kompetensi memiliki efek positif pada kualitas audit, Etika profesional memperkuat pengaruh pengalaman kerja pada kualitas audit, dan Etika profesional memperkuat pengaruh kompetensi pada kualitas audit.
\end{abstract}

Kata Kunci: Independensi, Pengalaman Kerja, Kompetensi, Etika Profesional, Kualitas Audit.

\section{INTRODUCTION}

An audit is a systematic examination conducted by financial statements prepared by management and finance, to provide financial statements (Agoes, 2004). The financial statements are summaries of the process of recording the financial transactions that occurred during the year. The financial statements based on generally accepted accounting principles (Financial Accounting Standards), which are applied consistently and do not contain material errors are reasonable financial statements. The financial statements provide a variety of financial information that is quantitative and necessary for decision-making by both internal and external parties company. To increase the quality of the financial report, auditing is needed. An audit can decrease the risk of financial report error, so it can increase the credibility of the financial report. So the information users require thirdparty services that are independent auditors to provide assurance that the financial statements are relevant and reliable and can increase the confidence of all parties concerned with the company (Singgih and Bawono, 2010).

The number of fraud conducted by external auditors during the audit process makes the quality of audits that produced questionable. Some example of cases, that occurred in Indonesia is 
the case of PT Kimia Farma in 2001, whereas the management of PT Kimia Farma reported financial statements that have been audited by Hans Tuanakotta \& Mustofa with net profit of Rp 132 billion, while the ministry of SOEs and BAPEPAM restate the financial statements and profit generated only amounted to $\mathrm{Rp} 99.56$ billion, or overstated $\mathrm{Rp} 32.6$ billion ( $24.70 \%$ of reported initial profit). This case example indicates low audit quality. The other case happened to the two members of the largest public accounting firm in the world of the Big Four, namely KPMG and PwC who were subjected to sanctions in the form of millions of pounds in fines for failing their audits. KPMG was fined more than US $\$ 6.2$ million by the Securities and Exchanges Commission (SEC) because of its audit failure on the Miller Energy Resources company that had increased its asset value. The assets of the Miller Energy Resources increase by 100 times the real value in the financial statements in 2011. KPMG also issued an unqualified opinion on the financial statements. PwC was fined GBP 5.1 million and was criticized by the Financial Reporting Council in the UK after PwC admitted wrongly in its audit of RSM Tenon Group in the 2011 financial year (Priantara, 2017).

Public accounting firm's audit failures on financial statements are generally caused by public accountants and their auditing teams not implementing audit standards as expected. Objectivity, professional accuracy, tiered supervision will occur, if risk analysis does not work so that an audit failure occurs. The impact is damage to credibility and trust in the public accounting firm, the relevant public accountant, and the audit profession in general. According to Al - Khaddash et al. (2013; in Adha, 2016), Audit quality is the probability that an auditor provides assurance that the audited financial statements are free from material misstatement. Based on survey doing by International Forum of Independent Auditor Regulator (IFIAR) stated that the level of audit quality still low. The problem in the managing the public accountant profession categorized as 5 issues. First, unstable competence and professional level of staff in each public accounting firm. Second, quality of control system in public accounting firm. Third, sunction maintenance to the violation of professional standard and law regulation. Fourth, the level of awareness in responsibility and competences in make the financial statement by management is low. Fifth, determining service fee (mediaindonesia.com).

An auditor must be independent in performing his duties. Accountants according to IAI, mentioned that the independence is the attitude expected from a public accountant to have no personal interest in carrying out its duties, which is contrary to the principle of integrity and objectivity. Besides independence, the auditor's work experience may also affect the level of audit quality result. The audit experience is related to how long the auditor works and how many audit cases have been completed. Code of ethics of public accountants is also a tool to provide confidence to clients, users of financial statements and the public in general about the quality of services provided. Competence is also one of the variables that can affect audit quality.

This study is a combination of previous research. These variables include independence, auditor work experience, competence of auditor, and audit quality adopted from their research. This study adopts a contingency framework to evaluate the relationship between independence, auditor work experience, and competence of auditor on the quality of the audit. This contingency approach performed by defining the professional ethics variable as a moderating variable that may influence strongly or weakly the relationship between competence, independence and audit quality. so the objectives of this study are is to examine the effect of independence, work experience and competence on audit quality, and also to examine whether professional ethics moderate the effect of independence, work experience and competence on audit quality.

\section{Behavioral Decision-making Theory}

This research uses behavioral decision making theory, where a person in making decisions is influenced by several factors. In this context, the auditor is an external party that makes an audit opinion in the financial statements of a company, so that the auditor in carrying out his duties in making decisions must be in accordance with the actual situation. This theory states that a person has limited knowledge and acts based on his perception of the situation faced and any factors such as self-interest, decision maker usually not use rational mind when make a decision. Auditors who are afraid of a downward reputation will tend to provide qualified opinion on problematic firms, whereas 
auditors who ignore their economic interests will be less likely to give unqualified opinions to troubled firms (Ariati, 2014). In this study, the use of decision-making theory because researchers will conduct a perceptual study to determine the factors that affect auditors on audit quality, and the accuracy of the judgment generated by the auditor in completing the audit work gives effect to the final conclusion (opinion) that the result indirectly influences the decision to be taken by the users of information that rely on audited financial statements.

\section{Audit Quality}

Arens et al., (2011: 105; in Saputra, 2015) state audit quality means how well an audit detects and report material misstatements in financial statements, the detection aspects are a reflection of auditor competence, while reporting is a reflection of ethics or auditor integrity, particularly independence. In addition, public accountants must also be guided by the Standards of Professional Public Accountants (SPAP) established by the Indonesian Institute of Accountants (IAI), in this case is auditing standards. The audit has a function as a process to reduce diversification information available between managers and shareholders by using outside parties to provide validation to the financial statements. Users of financial statements, especially shareholders will make decisions based on reports made by the auditor. This means that auditors have an important role in approving a company's financial statements. The Indonesian Institute of Accountants (IAI) states that audits conducted by auditors are said to be qualified, if they meet auditing standards and quality control standards.

\section{Independence}

Independence is a mental attitude free from influence, not controlled by others and not dependent on others. Independence also means the existence of honesty in the auditor in considering facts and the existence of objective consideration is not impartial in the auditor in formulating and expressing his opinion (Mulyadi, 2012). According Arens et al. (2004) the independent mental attitude is independence in fact or independence in appearance. Independence in fact (actual independence) exists when the auditor is perfectly capable of maintaining an unbiased attitude of auditing, while independence in appearance is the result of another interpretation of this independence.

Independence is an attitude that is not influenced by anyone, is not controlled by anyone and does not take sides with anyone. This character is very important for the public accounting profession in carrying out an audit of its clients. Trust is given by clients to public accountants in conducting audits and users of financial statements in order to prove the fairness of financial statements that have been compiled by the client. Independence according to Halim et al. (2014) has a positive effect on audit quality. According to Suyono (2012) independence also positively has an effect on audit quality partially. According to Futri and Juliarsa (2014) independence affected audit quality simultaneously and partially. Behavioral decision-making theory explains that an auditor in making decisions is influenced by several factors, one of which is independence. An independence auditor will make decisions in accordance with the facts and not be influenced by anyone, thus the more independent an auditor is the better the quality of the audit produced. Based on that explanation, the hypothesis can be determined as follows.

$\mathrm{H}_{1}$ : Auditor's independence has a positive effect on audit quality

\section{Work Experience}

Knoers and Haditono (1999; in Furyadi and Kurnia, 2015) define work experience as a learning process and enhance the development of better self-potential with formal and non-formal education, as well as the process of becoming someone who has a higher ability in the field of work. Work experience relates to how long an auditor works and how many cases have been completed. The more often the auditor handles audit cases will improve the quality of audits generated, especially in making audit judgment.

The experience of public accountants will continue to increase along with the increasing number of audits performed and the complexity of audited corporate financial transactions that will 
add and expand its knowledge in the field of accounting and auditing (Christiawan, 2002). In behavioral decision making theory explains that in making a decision will be influenced by many things. in this case the auditor's work experience is very influential on the auditor's decision to provide an audit opinion. The results of Silvia (2014) study show that work experience positively has a significant effect on audit quality. This shows that the more hours an auditor has in auditing a company's financial report will have greater influence on audit judgment. Based on the explanation, work experience has a positive effect on audit quality produced, because the more experienced an auditor is in carrying out his duties, the smaller the errors that occur so that the audit quality is higher. Based on that explanation, the hypothesis can be determined as follows.

$\mathrm{H}_{2}$ : Auditor's work experience has positive effect on audit quality

\section{Competence}

According to Dinata (2006; in Ariati (2014), competence is the overall knowledge, ability or skill and work attitude plus personality attributes possessed by a person. Based on the LOMA competency dictionary in Ariati (2016), Competence is defined as personal aspects of a worker that allows him to achieve superior performance. These personal aspects include the nature, motives, value systems, attitudes, knowledge and skills where competence will direct behavior, while behavior will produce performance. Murtanto (1998; in Alim, 2007) mentions that the competency component for auditors in Indonesia consists of; a) Component of knowledge, this component is an important component in a competency which includes knowledge of facts, procedures and experience. Kanfer and Ackerman (1989; in Alim, 2007) also state that experience will provide results in gathering and providing progress for knowledge, b) Characteristics of psychology, this characteristic feature is an important element in audit competence, such as the ability to communicate, creativity, and the ability to work with others.

Auditor competence is a qualification needed by the auditor to carry out audits correctly. Auditors who are highly educated will have a broader view of things. The auditor will increasingly have a lot of knowledge about the field he is engaged in so that he can find out various problems in more depth. Within sufficient knowledge, auditors will find it easier to keep up with increasingly complex developments. Harjanto (2014) in his research shows that competence has a positive effect on audit quality. The results of Alim et al research (2007) also showed that competency positively has a significant effect on audit quality. This shows the more competent an auditor is, the better the audit quality is produced. Based on that explanation, the hypothesis can be determined as follows.

$\mathrm{H}_{3}$ : Auditor's competence has a positive effect on audit quality

\section{Effect of Interaction between Independence and Audit Quality}

An auditor in performing his duties should pay attention to professional ethics as a public accountant. Based on the results of Harjanto's research (2014), auditor ethics strengthens the influence of auditor independence on audit quality, this indicates that the auditor's ethics influence an auditor to be independent, and the higher the auditor's independence the better the audit quality produced. This is in line with the theory of decision making where ethics and independence are internal auditor factors that can influence the auditor in making decisions. Based on that explanation, the hypothesis can be determined as follows.

$\mathrm{H}_{4}$ : professional ethics strengthens the effect of independence on audit quality

\section{Effect of Interaction between Work Experience and Audit Quality}

Professional ethics is very important for an auditor in carrying out his duties as an auditor. Experience also has a role in determining auditor performance. Auditors who have long work experience will better understand about auditor ethics in accordance with the code of ethics of public accountants, and it will affect the audit quality that will be produced. Based on Harjanto (2014), in his research stated that auditor ethics strengthens the influence of work experience on audit quality. This shows that the more experienced, the auditor will be better able to carry out audit tasks that can improve audit quality. Based on that explanation, the hypothesis can be determined as follows.

$\mathrm{H}_{5}$ : professional ethics strengthens the effect of work experience on audit quality 


\section{Effect of Interaction between Competence and Audit Quality}

An auditor who has high competence in carrying out an audit will always adhere to the audit principles and comply with the applicable code of ethics to be able to produce high audit quality. In producing reports that have high audit quality, an auditor must comply with the auditors' ethics that have been established. The higher the auditor adheres to the auditor's ethics, the higher the audit quality will be. This is supported by Ramadhani (2015) and Nasrullah et al (2014) in their research shows that interaction between competency and Auditor ethics has a significant effect on Audit Quality.

Arens et al., (2012: 78) defines ethics as a moral principle or value possessed by each individual. Ethics is the value that comes from society to regulate human behavior that is spiritual and unethical behavior in the form of oral arrangement (custom) and there is written or code of ethics (Agoes, and Ardana, 2012). According to Arens et al., (2012), professionalism is the responsibility of behaving more than the responsibilities afforded to the auditor and more than following the legislative (written) and community (unwritten) regulations. Based on the explanation can be concluded that auditor professional ethics is a moral principle or values held by the auditor to act professionally in accordance with professional standards. Professional ethics for auditors is called the code of professional accountant ethics. Based on that explanation, the hypothesis can be determined as follows.

$\mathrm{H}_{6}$ : professional ethics strengthens the effect of competence on audit quality

\section{RESEARCH METHODOLOGY}

Type of this research is a survey with quantitative research approach. Data used in this study is primary data that obtained through questionnaires distributed to respondents (auditors) in DKI Jakarta. The data can be measured by the numerical scale or in the form of numbers. The population of this study is all auditors in the public accounting firm in Jakarta. The sample of this study is determined by purposive sampling method. In this sample determination, there are two specific criteria for the auditor to serve as a sample (1) public accounting firm obtained license from minister of finance, (2) not under leave condition. This study use three variables, there are variable dependent, variable independent and moderating variable. Variable dependent of this study is audit quality (Y). Variable independent of this study are auditor's independence $\left(\mathrm{X}_{1}\right)$, auditor's work experience $\left(\mathrm{X}_{2}\right)$, and auditor's competence $\left(\mathrm{X}_{3}\right)$. For moderating variable, this study uses professional ethics $\left(\mathrm{X}_{4}\right)$. Likert scale is used to measure variable by giving a score of 1 to 5 on each instrument. Respondents were asked to give an opinion on each item of questions ranging from strongly agree to strongly disagree.

Data analysis techniques used in this study are (1) statistical descriptive test, (2) data quality test which consists of validity tests and reliability tests used to determine the quality of the instruments to be distributed to respondents to test validity and reliability, the author uses S1 students majoring in accounting who have taken audit and financial accounting courses, (3) assumption classic test consisting of normality test, multicollinearity test and heteroscedasticity test, (4) hypothesis testing using multiple linear regression, moderated regression analysis, t-test, F-test, and determinant coefficient.

\section{RESULT AND DISCUSSION \\ Descriptive Statistics of Research Data}

The results of descriptive statistical analysis, for the independence variable $\left(\mathrm{X}_{1}\right)$ has an average value of 3.85 in the agreed quadrant, indicating that respondents have a high perception of independence. Work experience variable $\left(\mathrm{X}_{2}\right)$ has an average value of 4.27, this indicates that respondents have a high perception of work experience. Then the competency variable $\left(\mathrm{X}_{3}\right)$ has an average value of 4.087 which indicates that respondents have a fairly high perception of competence. Professional ethical moderation variables $\left(\mathrm{X}_{4}\right)$ have an average value of 4,050 which indicates that respondents have a high perception of professional ethics. Audit quality variable $(\mathrm{Y})$ has an average value of 4,118 which indicates that respondents have a high perception of audit quality. 


\section{Quality Test Data}

Quality test data using reliability and validity test. The results of the calculation or the results of Corrected Item-Total Correlation, Pearson Product Moment correlation in the statement item independence variable is greater than the $r_{\text {table }}$ value or greater than 0.361 at the 5\% significance level, so all statement item of independence variable $\left(\mathrm{X}_{1}\right)$ are stated valid. The results of the calculation or the results of Corrected Item-Total Correlation, Pearson Product Moment correlation in the work experience variable statement item is greater than the $r_{\text {table }}$ value or greater than 0.361 at the $5 \%$ significance level, so all statements item of work experience variable $\left(\mathrm{X}_{2}\right)$ declared valid. The results of the calculation or the results of Corrected Item-Total Correlation, Pearson Product Moment correlation in the statement item competency variable are greater than the $r_{\text {table }}$ value or greater than 0.361 at the $5 \%$ significance level, so all statements item of competence $\left(\mathrm{X}_{3}\right)$ are stated valid.

The results of the calculation or the results of Corrected Item-Total Correlation, Pearson Product Moment correlation in the statement items of professional ethical variables are greater than the $r_{\text {table }}$ value or greater than 0.361 at the $5 \%$ significance level, so all the items of professional ethics statements are $\left(\mathrm{X}_{4}\right)$ declared valid. The results of the calculation or the results of Corrected ItemTotal Correlation, Pearson Product Moment correlation in the audit quality variable statement item is greater than the $r_{\text {table }}$ value or greater than 0.361 at the $5 \%$ significance level, so all statement item in variable of audit quality $(\mathrm{Y})$ declared valid. The results of research instrument reliability testing which can be interpreted that the Cronbach Alpha $(\alpha)$ audit quality $(\mathrm{Y})$, independence $\left(\mathrm{X}_{1}\right)$, work experience $\left(\mathrm{X}_{2}\right)$, competence $\left(\mathrm{X}_{3}\right)$, and professional ethics $\left(\mathrm{X}_{4}\right)$ is greater than Cronbach Alpha Minimum value is 0.60 , so all items in the statement instrument are declared reliable.

\section{Assumption Classic Test}

The results of the normality test conducted obtained by the results of normality testing using the Kolmogorov Smirnov One Sample test, it can be seen that the asymptotic value is $0.118>0.05$. Therefore, the regression model data shows a normal distribution. Based on the conclusions of the multicollinearity test, it is known that the VIF values of the variables independence, work experience, competence, professional ethics and audit quality each have a value of less than 10 . Tolerance values in the variables of independence, work experience, competence and audit qualifications are more from 0.10 . Therefore, it can be stated that there is no multicollinearity in the multiple regression model. The results of heteroscedasticity test with a significant value of the independence variable which is 0.088 work experience 0.028 competencies 0.305 , and professional ethics 0.347 . From these results it can be seen that there are symptoms of heteroscedasticity, so to overcome this data transformation is done using the transformation of natural logarithms. The results of heteroscedasticity tests using the transformation of natural logarithms. The transformation obtained significant values of the variables of independence, work experience, competence, professional ethics and audit quality, each of which has a value greater than the value of $\alpha(0.05)$. Therefore, it can be stated that there is no heteroscedasticity in the multiple regression model in this study.

\section{Multiple Regression Analysis}

Table 1. shows for us about multiple regression analysis that using in this research.

Table 1. Multiple Regression Analysis

\begin{tabular}{cccc}
\hline Variable & Regression Coefficient & $\mathrm{t}_{\text {statistic }}$ & Sig. \\
\hline Independence $\left(\mathrm{X}_{1}\right)$ & 0.005 & 0.054 & 0,957 \\
\hline Work Experience $\left(\mathrm{X}_{2}\right)$ & 0.302 & 2.580 & $0.012^{*}$ \\
\hline Competence $\left(\mathrm{X}_{3}\right)$ & 0.340 & 2.891 & $0.005^{*}$ \\
\hline Constant & 1.533 & 3.204 & $0.002^{*}$ \\
\hline Adjusted $R$ Square & 0.305 & & \\
\hline F statistic & 12.536 & & \\
\hline$*$ Sig $<0.05$ & 0.000 & & \\
\hline
\end{tabular}

Based on the conclusions of multiple regression analysis in Table 1 above shows that the $t_{\text {statistic }}$ value is smaller than the value of $t$ table (1.992). Thus, $H_{0}$ is accepted and $H_{a}$ is rejected, this 
means that independence does not have a positive and significant effect on audit quality. Therefore, the first hypothesis state that independence has a positive effect on audit quality is rejected. Table 1 shows $t_{\text {statistic }}(2.580)$ is greater than the value of $t$ table (1.992) and a significance value of 0.012 $<0.05$. Thus, $\mathrm{H}_{0}$ is rejected and $\mathrm{H}_{\mathrm{a}}$ is accepted, this means that work experience has a positive effect on audit quality. Therefore, the second hypothesis state that work experience has a positive effect on the quality of the audit is accepted. Table 1 shows the value of $t_{\text {statistic }}(2.891)>t_{\text {table }}(1.992)$ and a significant value of $0.005 \leq 0.05$, which means that competency has a positive effect on audit quality in KAP in DKI Jakarta. Therefore, the third hypothesis state competence has a positive effect on audit quality is accepted.

\section{Moderate Regression Analysis}

The results of the moderated regression analysis show that the statistical value $(0.353)$ is smaller than the $t_{\text {table }}$ (1.992). This shows that $\mathrm{H}_{0}$ is accepted and $\mathrm{H}_{\mathrm{a}}$ is rejected, so that it can be said that professional ethics does not moderate the influence of independence on audit quality. Based on these results, the fourth hypothesis state that professional ethics strengthen the effect of independence on audit quality is rejected. The results of $t_{\text {statistic }}$ value (2.013) are greater than the value of t table (1.992). This shows that $\mathrm{H}_{0}$ is rejected and $\mathrm{H}_{\mathrm{a}}$ is accepted, which means that professional ethics variables can modify the influence of work experience on audit quality. Based on these results, the fifth hypothesis, namely professional ethics can strengthen the effect of work experience on audit quality is accepted. The results of $t_{\text {statistic }}$ (3.756) is greater than $t$ table (1.992), so $\mathrm{H}_{0}$ is rejected and $\mathrm{H}_{\mathrm{a}}$ is accepted. This result means that the variables of professional ethics can moderate the influence of competence on audit quality. So that the sixth hypothesis state professional ethics strengthens the influence of competence on audit quality is accepted.

\section{Discussion}

Based on statistical results, this research has several findings. First, effect of independence on audit quality. From the results of hypothesis testing it can be seen that independence has no effect on audit quality or the first hypothesis is rejected. This shows that good independence not always give good result on audit quality. Independence is the attitude of the auditor who is not affected by other parties in carrying out their work. But in reality, the auditor in carrying out his duties sometimes faces some pressure by the client which makes the auditor feel the ethical dilemma that can affect the auditor in making an audit opinion.

This is in line with the theory in this study, namely behavioral decision-making theory, where in this theory it is explained that someone in making decisions is influenced by various things. So that in this case the auditor could lose his independence in carrying out his duties which can influence in making decisions and cause the audit quality produced is not good. This research is in line with the research conducted by Priyambodo (2015) state that independence does not affect audit quality. This condition can occur when the auditor is in a dilemma condition, which affects his independence in carrying out his duties as an auditor. This study also supports previous research conducted by Wardani and Astika (2018) state that independence does not affect audit quality.

Second, effect of work experience on audit quality. Based on the hypothesis test that has been done, the results show that work experience has a positive effect on audit quality or the second hypothesis is accepted. The auditor's experience is a learning process and the development of the auditor's potential behaviour while interacting with the tasks performed during a certain period of time. The more experienced an auditor, the better the quality of the audit produced. The more experienced, the auditor is easy to find fault and find out the cause of the error. All experience gained will be used well by the auditor in carrying out the next work, so that the audit results will be more qualified than before.

Theoretically, this finding is in line with the theory of decision-making theory which states that in making decisions, someone is influenced by several factors. In this case, work experience is one of the important factors for auditors in making decisions when carrying out their duties. According to Kusharyanti (2003), an experienced auditor is expected to have a better understanding of financial statements so as to be able to provide a reasonable explanation for errors in financial 
statements. Experience will also have an impact on every decision taken in the audit so that every decision taken is expected to be the right decision. This indicates that the longer the auditor's working period, the better the quality of the audit produced. This research is in line with the research conducted by Dewi (2016), Indah (2010) state that auditor work experience has a positive effect on audit quality.

Third, effect of competence on audit quality. Based on the hypothesis test that has been done, it is known that the third hypothesis is accepted. Based on these results it can be concluded that competence has a significant positive effect on audit quality. This shows that the more competent an auditor the quality of audit that produce is better. Competence is the knowledge and expertise possessed by the auditor to complete the tasks for which he is responsible.

Based on the behavioral decision-making theory which states that in making a decision, someone will be influenced by several things. In this case, competence is a very influential thing for the auditor in making decisions regarding the results of his work (judgment / opinion). Competence relates to professional expertise possessed by auditors as a result of formal education, professional examinations and participation in training, seminars, symposiums. Alim, et al. (2007) added that auditors as the spearhead of the implementation of audit tasks must always increase their knowledge so that the application of knowledge can be maximized in practice. The application of maximum knowledge will certainly be in line with the increasing experience. So that when the auditor is competent then in making a decision or making an audit opinion will be in accordance with the actual situation.

This research is in line with research conducted by Wardani and Astika (2018), Pertiwi (2013), Aprianti (2010), Basmar and pura (2015) concluded that competence has a positive effect on audit quality. The more expert or competent an auditor, the better the audit quality produced will be. If the auditor has a good level of competency, the auditor will be easier to carry out audit tasks and if the competency level is low then the auditor will have difficulties in carrying out his duties which will result in low audit quality.

Fourth, interaction between professional ethics and independence on audit quality. Based on moderated regression analysis test, the result of fourth hypothesis is rejected. This shows that the ethics of the auditor cannot strengthen the influence of independence on the audit quality. An independent auditor will carry out his duties in accordance with existing procedures and not be affected by other parties. When an auditor is not independent in carrying out his duties, this means that the auditor has not applied his professional ethics in carrying out his work. This also makes professional ethics have no influence on the interaction of auditor independence with audit quality.

This research is not in line with the research conducted by Sulistiani et al. (2018) states that the ethics of auditors are able to moderate the influence of independence on audit quality. Independent auditors are certain to apply professional ethics in carrying out their duties. If an auditor behaves independently, he will give a true assessment of the financial statements being examined, without having any burden on any party. Then the assessment will reflect the actual conditions of the company being examined. Thus, the guarantee of the reports reliability provided by the auditor can be trusted by all interested parties.

However, this study is also in line with the research of Wardhani and Astika (2018), Deli et al. (2015) stated that professional ethics are not able to moderate independency to audit quality. The client is a party that has a large influence on the auditor. This can be seen from the current conditions where there are various regulations governing the cooperation of clients with auditors. Besides that, it is very difficult for an auditor to remain independent, especially if in addition to providing client financial statement audit services, the auditor also provides other non-audit services. Thus, the provision of non-audit services to the audit client, good relations with the client, or the length of the cooperation relationship with the client will make the auditor more difficult to maintain the attitude of independence and this will have an impact on the audit quality produced by the auditor.

Fifth, interaction between professional ethics and work experience on audit quality. From the test results it can be seen that the fifth hypothesis is accepted. This means that professional ethics can strengthen the influence of work experience on audit quality. The auditor's work experience is an activity to conduct financial report audits both in terms of the length of time and the number of 
assignments that have been handled. Auditors who have long experience in the task will of course be better at carrying out their duties resulting in good audit quality.

Ethics is a set of moral principles or values where in carrying out work, an auditor must also pay attention to it. In this study professional ethics is able to strengthen the influence of auditor work experience on audit quality. Professional ethics is able to strengthen the influence of work experience on audit quality, because an experienced auditor certainly understands the ethics of his profession. An auditor who has long worked and completed many audit tasks tends to be more biased to understand the problems that exist, so that in carrying out their duties work according to what they are and produce the right decisions so that the quality of the audit produced is also good.

Purnamasari, (2005; in Marbun and Azhari, 2015) concludes that an employee who has high work experience will have advantages in several ways including: 1) detecting errors, 2) understanding errors and 3) looking for causes of errors. So that this is in line with the decisionmaking theory behaviour, where when an auditor is experienced and able to detect errors correctly then the decision taken is also right by still applying the professional ethics as an auditor so that the quality of the audit produced is also good. This research is in line with the research of Dewi (2015) which states that the more experienced an auditor, the better the quality of the audit produced. So that professional ethics applied by experienced auditors will strengthen the influence of work experience on audit quality.

Sixth, interaction between professional ethics and competence on audit quality. Based on the test results it can be seen that the sixth hypothesis is accepted. This means that professional ethics can strengthen the influence of competence on audit quality. Competence is the auditor's ability to complete his task. Auditors who have good competence can produce good audit quality and apply professional ethics as well. In general, this can be explained that audit ethics performed well by auditors will increase the influence of competencies on audit quality. Auditors' ethics are not only in behavior, but ethics codes of an auditor who must also be upheld in carrying out their duties, to obtain quality audit results. This is in line with the behavioral decision-making theory, where competence is an influential thing for the auditor in determining audit opinions. Auditors who have high competence will apply professional ethics and provide audit opinions according to the actual conditions so as to improve audit quality. The existence of ethical auditors also results in higher auditors' competencies, so that they can produce good audit quality. This research is in line with the Nasrullah et al. (2014), Wardhani and Astika (2018) which state that professional ethics can strengthen the influence of auditor competence on audit quality.

Overall, this empirical result consistent with Behavioral Decision-Making Theory. Where in the theory explained that someone in making decisions is influenced by various factors, both factors from internal or external. In this study, the auditor as the party that makes the audit opinion, in making decisions is influenced by several things such as independence, work experience, competence and professional ethics so that the audit quality produced by the auditor can be maintained.

\section{CONCLUSION}

This study aims to determine the effect of independence, work experience and competence on audit quality with professional ethics as a moderating variable. Based on the results of the analysis that has been done, conclusions can be drawn as follows. First, independence has no effect on audit quality at the Public Accountant Firm in DKI Jakarta. It means that an auditor in carrying out his duties can still be influenced by other parties that make the result of audit quality is not good. This result support previous research conducted by Wardhani and Astika (2018) which stated that independence has no effect on audit quality. Second, work experience has a positive effect on audit quality at Public Accounting Firms in DKI Jakarta. It means that more experienced an auditor, audit quality that produced is better. It's support study conducted by Dewi (2016). Third, competence has a positive effect on audit quality in public accounting firms in DKI Jakarta. This shows that competence is an important thing that the auditor must have in carrying out his duties. Therefore, the more competent the auditor, audit quality produced by an auditor also increases.

Fourth, professional ethics cannot strengthen the effect of independent on audit quality at Public Accounting Firm in DKI Jakarta. If an auditor not independent, it means that auditor not apply 
professional ethics. Fifth, professional ethics strengthens the effect of auditor work experience on audit quality at the Public Accounting Firm in DKI Jakarta. Auditor with high level of experience will understanding the professional ethics, so the auditor will apply the ethical code, so in make an opinion it will be based on the reality. Sixth, professional ethics strengthens the effect of competence on audit quality in Public Accounting Firms in DKI Jakarta. Means that competent auditor will have high ethical standards so that it can produce good audit quality. This results related with behavioral decision-making theory, which is in make decision auditor will influence by other things such as work experience, competence and professional ethics that will affect in audit quality produced.

Based on the conclusions above, there are implications of this research, that is, public accountant offices must maintain the competence and work experience of each auditor while implementing existing professional ethics so that the audit quality produced by an auditor can be carried out optimally and remain consistent with the SPAP. The further research needs to expand the study and develop a research model by including independent variables and other moderator variables. Further research also needs to develop a broader object of research to produce better research results more generally and objectively. further research needs to increase the number of public accounting offices studied in order to get better results.

\section{REFFERENCE}

Adha, B. R. 2016. Pengaruh Independensi Auditor, Profesionalisme Auditor, Etika Profesi Auditor, Akuntabilitas Auditor Terhadap Kualitas Audit pada Kantor Akuntan Publik Di Surabaya. Fakultas Ekonomi Dan Bisnis. Universitas Airlangga, Surabaya.

Agoes, S. 2004. AUDITING: Petunjuk Praktis Pemeriksaan Akuntan oleh Akuntan Publik (edisi 4). Jakarta: Salemba Empat.

Alim, N. M., Hapsari, T., Purwanti, L. 2007. Pengaruh Kompetensi dan Independensi Auditor terhadap Kualitas Audit dengan Etika Auditor sebagai Variabel Moderasi. Simposium Nasional Akuntansi X. 1-26.

Arens, A. A., Elder, Randal J., Beasley, Mark S. 2012. Auditing and Assurance Services (14th edition). New Jersey: Pearson Education, Inc.

Ariati K. K. 2014. Pengaruh Kompetensi Auditor terhadap Kualitas Audit dengan Kecerdasan Spiritual sebagai Variabel Moderasi Studi Persepsi Auditor pada Badan Pengawas Keuangan dan Pembangunan Provinsi Jawa Tengah. Skripsi. Fakultas Ekonomi Dan Bisnis Universitas Diponegoro, Semarang.

Basmar, N.A. and Pura, R. 2015. Pengaruh Kompetensi Auditor terhadap Kualitas Audit pada BPK RI Perwakilan Provinsi Sulawesi Selatan. ASSETS. 5. 1-12.

Deli, L., Fatma, A., Syarif, F. 2015. Faktor - Faktor yang Mempengaruhi Kualitas Audit dengan Etika Auditor sebagai Moderating Variable. Jurnal Riset Akuntansi Dan Bisnis. 15. 1-17.

Dewi, A. C. 2016. Pengaruh Pengalaman Kerja, Kompetensi, dan Independensi terhadap Kualitas Audit dengan Etika Auditor sebagai Variabel Moderasi. Skripsi. Fakultas ekonomi, Universitas Negeri Yogyakarta, Yogyakarta.

Dewi, S.C. 2015. Pengaruh Pengalaman Kerja, Independensi, Objektifitas, Integritas, Kompetensi, dan Etika Auditor terhadap Kualitas Hasil Audit. Skripsi. Fakultas Ekonomi, Universitas Pandanaran, Semarang.

Halim, A., Sutrisno, T., Achsin, M. 2014. Effect of Competence and Auditor Independence On Audit Quality with Audit Time Budget and Professional Commitment as A Moderating Variable. International Journal of Business and Management Invention. 3. 64-74.

Harjanto, P. A. 2014. Pengaruh Kompetensi, Independensi, Objektivitas, Akuntabilitas dan Integritas terhadap Kualitas Audit dengan Etika Auditor sebagai Variabel Moderasi (Studi Empiris KAP di Semarang). Skripsi. Fakultas Ekonomika Dan Bisnis Universitas Diponegoro, Semarang.

Indah, S. N. M. 2010. Pengaruh Kompetensi dan Independensi Auditor terhadap Kualitas Audit (Studi Empiris Pada Auditor KAP Di Semarang). Skripsi. Fakultas Ekonomi Universitas Diponegoro Semarang.

Mulyadi. 2012. Auditing (edisi 6). Jakarta: Salemba Empat. 
Nasrullah, Puspa, D.F., Herawati. 2014. Pengaruh Kompetensi, Independensi dan Pengalaman Kerja terhadap Kualitas Audit dengan Etika Auditor sebagai Variabel Moderasi. Skripsi. Fakultas Ekonomi, Universitas Bung Hatta, Sumatera Barat.

Priantara, D. 2016. Refleksi untuk Profesi Auditor atas Kasus KPMG dan PwC. Warta Indonesia. Accessed from https://www.wartaekonomi.co.id

Priyambodo, D. 2015. Pengaruh Kompetensi, Independensi, Pengalaman Kerja dan Akuntabilitas terhadap Kualitas Audit dengan Etika sebagai Variabel Moderating. Skripsi. Fakultas Ekonomi Dan Bisnis. Universitas Muhammadiyah Surakarta.

Ramadhani, N. 2015. Pengaruh Kompetensi dan Independensi terhadap Kualitas Audit dengan Etika Auditor sebagai Variabel Moderasi (Studi Empiris pada Kantor Akuntan Publik di Kota Surakarta dan Yogyakarta). Skripsi. Fakultas Ekonomi Dan Bisnis Universitas Muhammadiyah Surakarta.

Saputra, W. 2015. The Impact of Auditor's Independence on Audit Quality: A Theoretical Approach. International Journal of Scientific \& Technology Research. 4. 2277-8616.

Singgih, E. M., Bawono, I. R. 2010. Pengaruh Independensi, Pengalaman, Due Professional Care dan Akuntabilitas terhadap Kualitas Audit (Studi pada Auditor Di KAP Big Four di Indonesia). Simposium Nasional Akuntansi XIII Purwokerto 2010. Accessed from www.snal3purwokerto.com

Suyono, E. 2012. Determinant Factors Affecting the Audit Quality: An Indonesian Perspective. Global Review of Accounting and Finance. 3. 42-57.

Wardhani, A.A.I.T.W and Astika, I.B.P. 2018. Pengaruh Kompetensi, Akuntabilitas, dan Independensi pada Kualitas Audit dengan Etika Auditor sebagai Variabel Moderasi. E-Jurnal Akuntansi Universitas Udayana. 23.1.31-59. 